\title{
Evaluation Method of Ideological and Political Curriculum Reform Effect in Colleges and Universities Based on Fine-grained Learning
}

\author{
Tianyi Sun ${ }^{1, *}$ Xia Zhao ${ }^{2}$

\begin{abstract}
${ }^{1}$ Youth League Committee, The First Affiliated Hospital of China Medical University
${ }^{2}$ Youth League Committee, The First Affiliated Hospital of China Medical University

${ }^{*}$ Corresponding author. Email: 20142051@cmu.edu.cn
\end{abstract}

\begin{abstract}
In order to effectively meet the needs of teaching effect evaluation, reduce the error of effect evaluation results and improve the accuracy of evaluation results, an effect evaluation method of Ideological and Political Curriculum Reform in Colleges and Universities based on fine-grained learning is proposed. By defining the emotional ontology of fine-grained learning and classifying the emotional set of knowledge point learning, the emotional feedback of students to knowledge and teachers is constructed. According to the defined fine-grained learning emotional ontology, the emotional degree of learning effect is measured, the learning efficiency of Ideological and political curriculum is evaluated, and the effect of Ideological and Political Curriculum Reform of fine-grained learning is evaluated. The experimental results show that. The error of the evaluation results of the proposed method is small, which can effectively improve the accuracy of the evaluation results and meet the needs of teaching effect evaluation.
\end{abstract}

Keywords: Fine grained learning, Ideological and political courses in Colleges and universities, Curriculum reform, Effect evaluation, Emotional value, Knowledge point path

\section{INTRODUCTION}

In the process of Ideological and Political Curriculum Reform in recent years, we pay more attention to the reform of curriculum teaching methods. Modern curriculum teaching pays more attention to students' subject status and emphasizes students' learning initiative. Students' subject status gradually rises with the continuous research on curriculum education. Whether it is the traditional face-to-face classroom or the online classroom in the Internet era, curriculum reform is very important [1]. However, evaluating the effect of curriculum reform can improve students' learning enthusiasm and meet the needs of modern education.

In view of the current evaluation methods, artificial intelligence algorithm and support vector machine are mainly used to establish teaching effect evaluation model and realize teaching effect evaluation. This method has certain effectiveness, but the accuracy of evaluation results is low [2]. Therefore, this paper proposes an evaluation method of the effect of Ideological and Political Curriculum Reform in
Colleges and Universities based on fine-grained learning. Taking fine granularity as the evaluation factor, through fine granularity learning emotional ontology, the logical relationship in Ideological and political curriculum is established, and then the knowledge is divided according to the degree of difficulty. Finally, according to the classification, teachers are given the meaning of emotional expression in teaching methods. Based on the concept of finegrained learning [3], this concept enables the establishment of relationships for the assessment of pedagogical change. In the emotional education model, contact the individual changes of knowledge points and learning emotion, and use the model to evaluate the effect of students' Ideological and political curriculum reform.

\section{DEFINE THE EMOTIONAL ONTOLOGY OF FINE-GRAINED LEARNING}

There are nine elements in the collection of finegrained learning ontology, which are divided into 
students, teachers, courses, knowledge points, difficulty, knowledge point relationship collection, students' cognition, the classification of emotional feedback of learning subjects and the classification of emotional feedback by teachers. Each set in the fine-grained learning ontology has its own definition: the set of knowledge points includes conceptual knowledge, factual knowledge, metacognitive knowledge and procedural knowledge. The relationship set of knowledge points includes the relationship between the whole and part, causality, superior and subordinate relationship and sequential relationship. The learning stage of students' knowledge points is divided into three stages: memory understanding, analysis and application and creation [4]. Based on the above set relationship, students' emotions for knowledge point learning are classified, which is based on effective learning. Negative emotions include disgust, fear and anger. Negative emotions are based on learning problems. When students first face new knowledge, they are calm. If the absorption effect of knowledge is ideal, students emotions will develop to positive emotions, and if the effect is not ideal, they will develop to negative emotions.

From the perspective of curriculum analysis, explain the curriculum ontology meaning of the emotion of granular learning, and the corresponding relationship between relevant knowledge points, knowledge types and difficulty is shown in Table 1.

Table 1. Knowledge point correspondence

\begin{tabular}{|c|c|c|c|c|}
\hline $\begin{array}{l}\text { Num } \\
\text { ber }\end{array}$ & $\begin{array}{c}\text { Knowledge } \\
\text { point }\end{array}$ & $\begin{array}{l}\text { Knowledge } \\
\text { point type }\end{array}$ & $\begin{array}{l}\text { Degree of } \\
\text { difficulty }\end{array}$ & $\begin{array}{c}\text { Cognitive } \\
\text { goals }\end{array}$ \\
\hline 1 & $\begin{array}{c}\text { The essence of } \\
\text { money }\end{array}$ & $\begin{array}{l}\text { Metacognitiv } \\
\text { e knowledge }\end{array}$ & $\begin{array}{c}\text { More } \\
\text { difficult }\end{array}$ & $\begin{array}{l}\text { Understandin } \\
\text { g memory }\end{array}$ \\
\hline 2 & $\begin{array}{c}\text { Credit } \\
\text { instruments }\end{array}$ & $\begin{array}{l}\text { Metacognitiv } \\
\text { e knowledge }\end{array}$ & $\begin{array}{c}\text { More } \\
\text { difficult }\end{array}$ & $\begin{array}{l}\text { Understandin } \\
\text { g memory }\end{array}$ \\
\hline 3 & $\begin{array}{c}\text { Spiritual } \\
\text { civilization } \\
\text { construction }\end{array}$ & $\begin{array}{l}\text { Conceptual } \\
\text { knowledge }\end{array}$ & $\begin{array}{l}\text { General } \\
\text { difficulty }\end{array}$ & Evaluate \\
\hline 4 & $\begin{array}{l}\text { Government } \\
\text { responsibilities }\end{array}$ & $\begin{array}{l}\text { Conceptual } \\
\text { knowledge }\end{array}$ & $\begin{array}{l}\text { General } \\
\text { difficulty }\end{array}$ & $\begin{array}{l}\text { Understandin } \\
\text { g memory }\end{array}$ \\
\hline 5 & $\begin{array}{c}\text { People's } \\
\text { democratic } \\
\text { dictatorship }\end{array}$ & $\begin{array}{l}\text { Metacognitiv } \\
\text { e knowledge }\end{array}$ & $\begin{array}{c}\text { More } \\
\text { difficult }\end{array}$ & Evaluate \\
\hline 6 & $\begin{array}{l}\text { Foreign } \\
\text { exchange }\end{array}$ & $\begin{array}{l}\text { Procedural } \\
\text { knowledge }\end{array}$ & $\begin{array}{l}\text { General } \\
\text { difficulty }\end{array}$ & $\begin{array}{l}\text { Understandin } \\
\text { g memory }\end{array}$ \\
\hline 7 & $\begin{array}{c}\text { Government } \\
\text { prestige }\end{array}$ & $\begin{array}{l}\text { Practical } \\
\text { knowledge }\end{array}$ & $\begin{array}{l}\text { General } \\
\text { difficulty }\end{array}$ & Evaluate \\
\hline 8 & Responsibility & $\begin{array}{l}\text { Procedural } \\
\text { knowledge }\end{array}$ & $\begin{array}{l}\text { General } \\
\text { difficulty }\end{array}$ & $\begin{array}{l}\text { Analysis and } \\
\text { Application }\end{array}$ \\
\hline 9 & obligation & $\begin{array}{l}\text { Metacognitiv } \\
\text { e knowledge }\end{array}$ & $\begin{array}{l}\text { General } \\
\text { difficulty }\end{array}$ & Evaluate \\
\hline 10 & $\begin{array}{l}\text { Law and } \\
\text { morality }\end{array}$ & $\begin{array}{l}\text { Procedural } \\
\text { knowledge }\end{array}$ & $\begin{array}{c}\text { More } \\
\text { difficult }\end{array}$ & $\begin{array}{l}\text { Analysis and } \\
\text { Application }\end{array}$ \\
\hline 11 & $\begin{array}{c}\text { A moderately } \\
\text { prosperous } \\
\text { society }\end{array}$ & $\begin{array}{l}\text { Conceptual } \\
\text { knowledge }\end{array}$ & $\begin{array}{l}\text { General } \\
\text { difficulty }\end{array}$ & $\begin{array}{l}\text { Analysis and } \\
\text { Application }\end{array}$ \\
\hline 12 & $\begin{array}{c}\text { Socialist } \\
\text { construction }\end{array}$ & $\begin{array}{c}\text { Practical } \\
\text { knowledge }\end{array}$ & $\begin{array}{l}\text { General } \\
\text { difficulty }\end{array}$ & $\begin{array}{l}\text { Analysis and } \\
\text { Application }\end{array}$ \\
\hline
\end{tabular}

The relationship between the knowledge points in Table 1 and the collection of others constructs the emotional feedback of students on knowledge and teachers on learning emotion.

\section{AFFECTIVE DEGREE OF LEARNING EFFECT BASED ON ONTOLOGY}

According to the analysis of the definition of learning emotion, students' learning emotion for knowledge points is mastered. Quantify the students' learning emotion, and use the letter $\mathrm{X}$ to represent the quantified emotion value. Calculate the average value and range of different learning emotions, and compare the impact of emotional values on learning effect [5-6]. Calculate the absolute value of learning emotion value and the coefficient of absolute value. The association path between two interrelated knowledge points determines the type of relationship between knowledge points. For example, if knowledge point a is the cause of 
knowledge point $\mathrm{B}$, the relationship between knowledge points a and B is causal.

Each student has different understanding of knowledge points. The emotional value of knowledge points in the grouping of individual knowledge points is defined as $\mathrm{x} 1$, which is calculated and measured by the above calculation method. The emotional value of knowledge on different connection paths of students is defined as X2, and the average emotional value of relationship path of student knowledge points is $\mathrm{X} 3$, which is measured by the index of relationship path. The statistical metrics of the path are shown in Table 2 .

Table 2. Path measurement index of learning emotions

\begin{tabular}{|c|c|c|}
\hline Number & $\begin{array}{l}\text { Statistical } \\
\text { metrics }\end{array}$ & $\begin{array}{l}\text { Statistical measurement } \\
\text { method }\end{array}$ \\
\hline 1 & $\begin{array}{l}\text { Proportional } \\
\text { relative index }\end{array}$ & $\begin{array}{l}\text { Proportion of learning } \\
\text { emotion polarity changing } \\
\text { from positive to negative }\end{array}$ \\
\hline 2 & $\begin{array}{l}\text { Proportional } \\
\text { relative index }\end{array}$ & $\begin{array}{l}\text { Proportion of learning } \\
\text { emotion polarity changing } \\
\text { from negative to positive }\end{array}$ \\
\hline 3 & Average index & $\begin{array}{c}\text { Average value of affective } \\
\text { leaming }\end{array}$ \\
\hline 4 & $\begin{array}{l}\text { Mean difference } \\
\text { of variation index }\end{array}$ & $\begin{array}{c}\text { Average difference in change } \\
\text { value of leaming emotion } \\
\text { value }\end{array}$ \\
\hline 5 & $\begin{array}{l}\text { Mean difference } \\
\text { coefficient of } \\
\text { variation index }\end{array}$ & $\begin{array}{c}\text { Average difference } \\
\text { coefficient of change value of } \\
\text { leaming emotion value }\end{array}$ \\
\hline
\end{tabular}

Calculate the indexes in Table 2 of $\mathrm{x} 1, \mathrm{X} 2$ and $\mathrm{X} 3$. After calculating the emotional value indicators of each student, add them together to obtain the total number, and divide them by the total number of students to obtain the average value of students' emotional indicators.

\section{EVALUATE THE LEARNING EFFICIENCY OF FINE-GRAINED LEARNING}

Using the fine-grained learning classification model to evaluate the learning efficiency of students, to evaluate a single student, we should first compare the proportion of positive emotion value in learning emotion. The greater the proportion, the greater the emotional evaluation value. The smaller the range of emotion value, the higher the accuracy of emotion evaluation results.

The evaluation of learning effect of knowledge points is that when learning, the proportion of students' negative emotions to positive emotions is large, the proportion of students' positive emotions to negative emotions is small, and the overall learning effect of students is good. When a single student studies, he studies with positive and neutral emotions for a long time, accounting for a high proportion of the total learning time, indicating that the single learning effect is good [7]. The proportion of good single learning effect accounts for more than 4 / 5 of the learning times, indicating that the student's overall learning effect is good.

The average value and range of students' learning emotions are as small as possible, which proves that the learning effect is stable. The large values of average value and range indicate that the learning effect is unstable. Students' emotions change greatly in finegrained learning, so they need to adjust their mentality in time.

Before evaluating the learning effect of knowledge point relationship path, set the average value calculation formula of relationship path as:

$$
Y=\left\{\frac{\sum_{k=1}^{m} \operatorname{AveEmoDif}\left(s_{k}, p_{1}\right)}{n}, \ldots, \frac{\sum_{k=1}^{m} \operatorname{AveEmoDif}\left(s_{k}, p_{n}\right)}{n}\right\}
$$

In the formula, $y$ is the average value of the relationship path, the value range of emotional value is $1 \sim \mathrm{n}$, and the value $\mathrm{k}$ is selected between $1 \sim \mathrm{n}$ to meet $\mathrm{n} \geqslant \mathrm{K} \geqslant 1$. AveEmoDif represents the emotional change of a student learning knowledge points in the relationship path of knowledge points, $s_{k}$ is the informed value of student s learning $\mathrm{K}$ knowledge, and $p_{n}$ is the path. Finally, the above formula is used to evaluate the effect of Ideological and Political Curriculum Reform in Colleges and universities.

\section{EXPERIMENTAL ANALYSIS}

In order to verify the effectiveness of the evaluation method of the effect of Ideological and Political Curriculum Reform in Colleges and Universities Based on fine-grained learning, the proposed method is compared with the current method, and the evaluation effects of the two evaluation methods are compared.

\subsection{Experimental preparation}

250 students majoring in Ideological and Political Science in a university are selected and divided into two classes. There are 125 students in class A and class B, with a reasonable proportion of men and women. The two-stage learning effect evaluation is carried out from the aspects of autonomous learning ability, teacherstudent interaction and achievement feedback. 


\subsection{Experimental results and analysis}

Using the proposed method and the current method, the learning effect evaluation error results of the two learning stages are compared, and the evaluation error results of different methods are obtained, as shown in Figure 1.

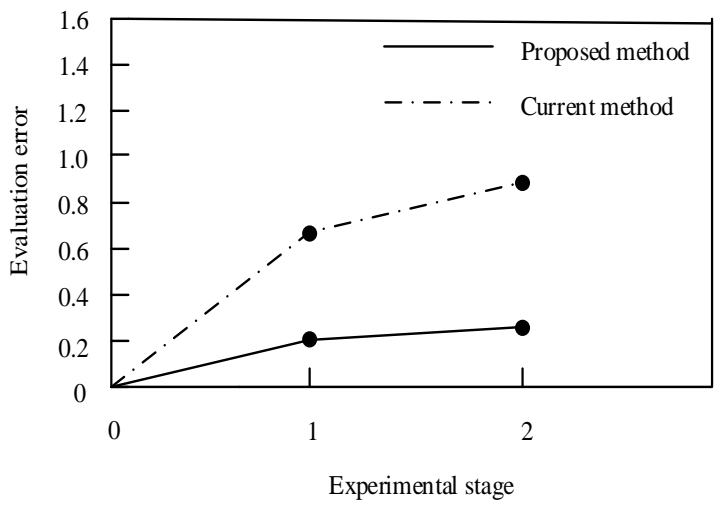

Figure 1 Comparison of evaluation results and errors of different methods

According to figure 1, in the evaluation of the effect of curriculum reform in the two learning stages, the evaluation error in the first learning stage of the current method is 0.67 and the evaluation error in the second learning stage is 0.88 , while the evaluation error in the first learning stage of the proposed method is 0.2 and the evaluation error in the second learning stage is 0.26 . Therefore, compared with the current method, the evaluation result error of the proposed method is small, the evaluation result error changes stably, and can effectively improve the accuracy of the evaluation result.

\section{CONCLUSION}

In order to effectively reduce the error of evaluation results of Ideological and Political Curriculum Reform in Colleges and universities and improve the accuracy of evaluation results, an evaluation method of Ideological and Political Curriculum Reform in Colleges and Universities Based on fine-grained learning is proposed. Taking the change of students' emotional value of knowledge point learning and the path relationship between knowledge points as evaluation factors, the evaluation effect of this evaluation method is closer to reality, and the evaluation results can be directly used as a reference to improve students' learning effect.

\section{ACKNOWLEDGMENTS}

Thank you for the fund support of Yunnan Province philosophy and social science planning project for this experiment. The project number is (yb2017038)

\section{REFERENCES}

[1] Doorsselaere J V. Connecting Sustainable Develop ment and Heritage Education? An Analysis of the Curriculum Reform in Flemish Public Secondary S chools[J]. Sustainability, 2021, 13(4):1-17.

[2] Liang H. Role of artificial intelligence algorithm fo $r$ taekwondo teaching effect evaluation model[J]. J ournal of Intelligent and Fuzzy Systems, 2021, 40 (2):3239-3250.

[3] Morales A, Costela F M, Woods R L. Saccade Lan ding Point Prediction based on Fine-Grained Learn ing Method[J]. IEEE Access, 2021, PP(99):1-1.

[4] Yang J. Research on the Innovation and Developm ent of Ideological and Political Education in Colleg es and Universities Based on Computer Technolog $\mathrm{y}[\mathrm{J}]$. Journal of Physics: Conference Series, 2021, 1744(3):032213 (4pp).

[5] Li X, Wang R. Research on the Learning Status an $\mathrm{d}$ Solutions of Ideological and Political Theory Cou rse in Colleges and Universities[J]. International Jo urnal of Social Science and Education Research, 20 19, 2(6):36-40.

[6] Hewage P, Trovati M, Pereira E, et al. Deep learnin g-based effective fine-grained weather forecasting model[J]. Pattern Analysis and Applications, 2021, 24(1):343-366.

[7] Xw A, Xm A, Qh B, et al. Fine-grained learning pe rformance prediction via adaptive sparse self-attent ion networks - ScienceDirect[J]. Information Scien ces, 2021, 545:223-240. 